\title{
PEMBUATAN ALAT LABORATORIUM FISIKA FAKULTAS ILMU TARBIYAH DAN KEGURUAN IAIN WALISONGO UNTUK PRAKTIKUM OSILASI CAIRAN DAN AYUNAN MATEMATIS SECARA DIGITAL
}

\author{
Agus Sudarmanto \\ Dosen Jurusan Tadris Fisika FITK IAIN Walisongo
}

\begin{abstract}
Abstrak
Penelitian ini merancang dan merealisasikan pembuatan alat laboratorium Fisika Fakultas Tarbiyah IAIN secara digital yaitu pada praktikum osilasi cairan dan ayunan matematis.

Pembuatan alat laboratorium Fisika Fakultas Ilmu Tarbiyah dan Keguruan IAIN Walisongo untuk praktikum osilasi cairan dan ayunan matematis secara digital terdiri dari sumber cahaya, sensor cahaya yang keluarannya, dengan keypad sebagai masukannya kemudian diproses dengan mikrokontroler ATMega8535 dengan algoritma program kemudian hasilnya ditampilkan pada LCD (Liquid Cristal Display).

Hasil penelitian ini adalah bahwa pembuatan alat laboratorium fisika untuk praktikum osilasi cairan dan ayunan matematis secara digital sudah dapat berfungsi sesuai dengan yang diinginkan dan data hasil dari alat tersebut mendekati nilai percepatan gravitasi bumi sebenarnya yaitu sebesar $9,8 \mathrm{~m} / \mathrm{s}^{2}$.
\end{abstract}

Kata Kunci : Digitalisasi Alat Laboratorium, Percepatan Gravitasi 


\section{PENDAHULUAN}

Teknologi mikrokontroler saat ini berkembang dengan pesat, seiring dengan kemampuan ilmu pengetahuan dan teknologi. Dalam perkembangannya, teknologi ini tidak hanya berperan dalam satu bidang saja melainkan hampir di segala bidang kehidupan manusia. Banyak hal yang mungkin selama ini untuk menyelesaikan suatu permasalahan manusia membutuhkan biaya, waktu, tenaga yang cukup besar untuk penyelesaiannya, tetapi dengan adanya kemajuan teknologi mikrokontroler hal-hal tersebut dapat ditekan seminimal mungkin. (Link, Wolfgang, 1993)

Keuntungan yang diperoleh dengan adanya teknologi mikrokontroler ini adalah sebagai alat ukur dan otomasi secara digital dengan tampilan LCD. Pada bidang fisika, mikrokontroler digunakan sebagai pengontrol kerja sistem, dalam penelitian ini adalah digitalisasi pada alat praktikum pada Tadris Fisika yaitu tentang ayunan matematis dan osilasi cairan. Mikrokontroler ini akan mengolah data kemudian dengan algoritma program maka hasilnya akan ditampilkan pada LCD (Liquid Crystal Display).

Pada mata kuliah praktikum Fisika Dasar dan Gelombang di Tadris Fisika Fakultas Ilmu Tarbiyah dan Keguruan IAIN Walisongo Semarang dalam hal ini materi Praktikum Fisika Dasar tentang ayunan matematis dan Praktikum Gelombang tentang osilasi cairan masih menggunakan alat praktikum yang manual, sehingga tingkat kesalahan dalam hal pengambilan data masih besar, maka hasil akhir dari praktikum tersebut masih jauh dari yang diinginkan. Maka dari itu, sangat perlu sekali untuk membuat sebuah alat praktikum secara digital guna mengefisienkan waktu dan meminimalisasi tingkat kesalahan dalam pengambilan data, sehingga hasil akhirnya sesuai dengan yang diinginkan (sesuai dengan referensi). Tetapi praktikan juga tetap menggunakan alat yang manual supaya mahasiswa tahu dan paham akan petunjuk manual praktikum tersebut dan dalam perhitungan juga harus manual supaya praktikan tahu dan paham secara fisisnya, sedangkan alat digitalisasi hanya untuk membandingkan hasil akhir yang didapatkan apakah sudah sesuai yang di- 
inginkan atau belum.

\section{KERANGKA TEORI}

Sumber cahaya disini yang digunakan adalah sinar laser. Laser (singkatan dari bahasa Inggris: Light Amplification by Stimulated Emission of Radiation) merupakan mekanisme suatu alat yang memancarkan radiasi elektromagnetik, biasanya dalam bentuk cahaya yang tidak dapat dilihat maupun dapat lihat dengan mata normal, melalui proses pancaran terstimulasi. Pancaran laser biasanya tunggal, memancarkan foton dalam pancaran koheren. Sejak diperkenalkannya laser pada tahun 1960, sebagai sebuah penyelesaian suatu masalah, maka dalam perkembangan berikutnya laser telah digunakan secara meluas, dalam bermacam-macam aplikasi modern, termasuk dalam bidang optik, elektronik, optoelektronik, teknologi informasi, sains, kedokteran, industri, dan militer. (http://id.wikipedia. org/wiki/Laser, 2012)

Masalah utama dalam teknik pengukuran dan pengaturan secara elektronik adalah mengubah besaran fisik (misal : temperatur, kecepatan ayunan) menjadi besaran listrik yang proporsional. Pengubah yang melaksanakan hal ini secara mum disebut sebagai sensor. Sensor fotoelektrik terdiri dari atas LED berwarna merah atau LED infra merah yang menyinari fotodioda atau fototransistor sebagai penerimanya. Mereka tersedia sebagai satu kesatuan atau terpisah dalam masing-masing kotak. Kadang-kadang juga dilengkapi dengan lensa agar dapat mengenali sinyal kecil dengan lebih baik, atau untuk memperoleh jarak pengamatan yang lebih jauh. (Link, Wolfgang, 1993)

Mikrokontroler AVR (Alf and Vegard's Risc Processor) merupakan salah satu perkembangan produk mikroelektronika dari vendor Atmel. AVR merupakan teknologi yang memiliki kemampuan yang baik dengan biaya ekonomis yang cukup minimal. Mikrokontroler AVR memiliki arsitektur RISC 8 bit, dimana semua instruksi dikemas dalam kode 16 bit dan sebagian besar instruksi dieksekusi dalam 1 (satu) siklus clock, berbeda dengan instruksi MCS51 yang membutuhkan 12 siklus clock. Tentu saja 
itu terjadi karena kedua jenis mikrokontroler tersebut memiliki arsitektur yang berbeda. AVR berteknologi RISC (Reduced Instruction Set Computing), sedang MCS 51 berteknologi CISC (Complex Instruction Set Computing). Secara umum AVR dapat dikelompokkan menjadi 4 kelas, yaitu keluarga ATiny, keluarga AT90Sxx, Keluarga ATMega, dan AT86RFxx. Pada dasarnya yang membedakan masing-masing kelas adalah memori, peripheral, dan fungsinya. Dari segi arsitektur dan instruksi yang digunakan, mereka bisa dikatakan hampir sama. (Lingga. W. 2006)

Keypad 4x4 di sini adalah sebuah keypad dengan susunan empat baris dan empat kolom dengan sebuah common. Pada alat ini pin-pin pada keypad dihubungkan pada port B mikrokontroler ATMega8535. Keypad berfungsi untuk memasukkan data dan melakukan seting atau kontrol. Pengambilan data dari keypad dilakukan dengan menunggu adanya penekanan tombol keypad. Kondisi tidak ada penekanan tombol adalah high untuk semua pin keypad kecuali common yang terhubung ke ground atau FFh pada port mikrokontroler. Proses konversi tabel keypad dilakukan dengan menganggap data-data dari keypad sebagai suatu alamat memori di mana isi dari alamat tersebut adalah berupa data yang dianggap sebagai tanda saat tombol tersebut ditekan. (http://delta-electronic.com/article/wp-content/uploads/2008/09/an0060.pdf, 2012).

LCD Display modul M1632 buatan Seiko Inc, meskipun harganya sekitar lima kali lipat dibanding dengan LCD Module SEDI200 buatan Epson, tapi karena M1632 lebih dulu beredar di Indonesia dan lebih mudah didapat, masih merupakan pilihan banyak penggemar elektronik praktis. LCD display module M1632 terdiri dari dua bagian, yang pertama merupakan panel LCD sebagai media penampil informasi dalam bentuk huruf/ angka dua baris, masing - masing baris bisa menampung 16 huruf/angka.

Bagian kedua merupakan sebuah sistem yang dibentuk dengan mikrokontroler yang ditempel dibalik pada panel LCD, berfungsi mengatur tampilan LCD. Dengan demikian pemakaian 
LCD M1632 menjadi sederhana, sistem lain cukup mengirimkan kode - kode ASCII dari informasi yang ditampilkan. (http:// www.delta-elektronik.com,DatasheetLCD, 2012).

Gerak harmonik adalah gerak bolak-balik melalui suatu titik setimbang. Salah satu contoh gerak harmonik adalah ayunan sederhana atau ayunan bandul. Gaya yang mempengaruhi gerak ayunan adalah $\mathrm{F}=\mathrm{m} \cdot \mathrm{g} \sin \theta$, dengan $\theta$ adalah sudut simpangan dan 1 adalah panjang tali ayunan. Dengan mengambil sudut $\theta$ yang kecil (kurang dari $15^{\circ}$ ) maka dapat dianggap sebagai gerak harmonik sederhana.

Untuk sudut $\theta$ kecil $\operatorname{tg} \theta \sim \sin \theta=0$, maka busur lingkaran $\mathrm{s}$ sama dengan simpangannya (y).

$$
\begin{aligned}
& \left.\begin{array}{l}
\sin \theta=\frac{y}{\ell} \\
\sin \theta=\frac{F}{w}
\end{array}\right\} \frac{y}{\ell}=\frac{F}{w} \Longrightarrow \\
& \left.\begin{array}{l}
F=\frac{y}{\ell} \cdot m \cdot g \\
F=k \cdot y
\end{array}\right\} k=\frac{m \cdot g}{\ell}
\end{aligned}
$$

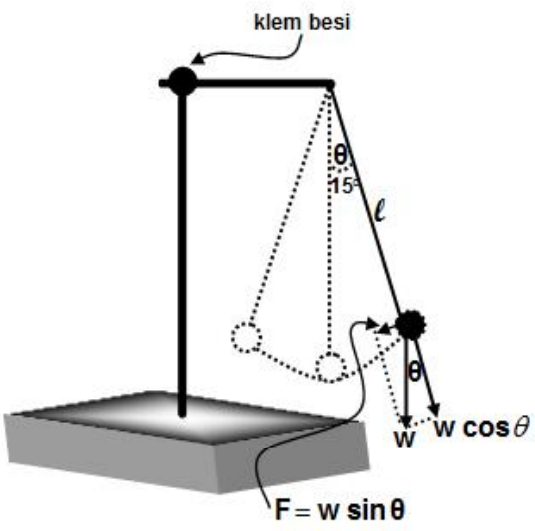

Berdasar persamaan $k$ diatas maka nilai periode $(\mathrm{T})$ dan frekuensi (f) ayunan sederhana masing-masing adalah:

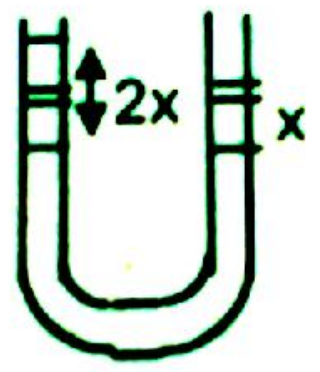

Gambar 2. osilasi cairan (Halliday, 1996) 
Jika permukaan zat cair pada kaki kiri tabung $\mathrm{U}$ naik $\mathrm{x} \mathrm{cm}$ dari permukaan awl, maka permukaan zat cair pada kaki kanan akan turun $\mathrm{x} \mathrm{cm}$, sehingga terdapat perbedaan tinggi kedua permukaan sebesar $2 x \mathrm{~cm}$. Perbedaan tinggi permukaan ini menyebabkan gaya sebesar $2 x \mathrm{~A} \rho g$ yang berlawanan dengan simpangan zat cair.

Menurut Hukum Newton II :

$$
m . a=F
$$

$$
l A \rho \frac{d^{2} x}{d t^{2}}=-2 A x \rho g
$$

$$
\frac{d^{2} x}{d t^{2}}+\frac{2 g x}{l}=0
$$

Jika $2 g / l=\omega^{2}$ dimana $\omega$ adalah frekuensi sudut osilasi dang mengingat bahwa $\omega=2 \pi / T$ maka periode osilasi tanpa redaman adalah :

$$
T=2 \pi \sqrt{\frac{l}{g}} \quad \text { atau } \quad g=4 \pi^{2} \frac{l}{T^{2}}
$$

\section{METODOLOGI PENELITIAN}

\section{Desain Digitalisai Alat}

Desain digitalisasi alat laboratorium fisika untuk praktikum osilasi cairan dan ayunan matematis secara digital adalah sebagai berikut : 
Ayunan Matematis

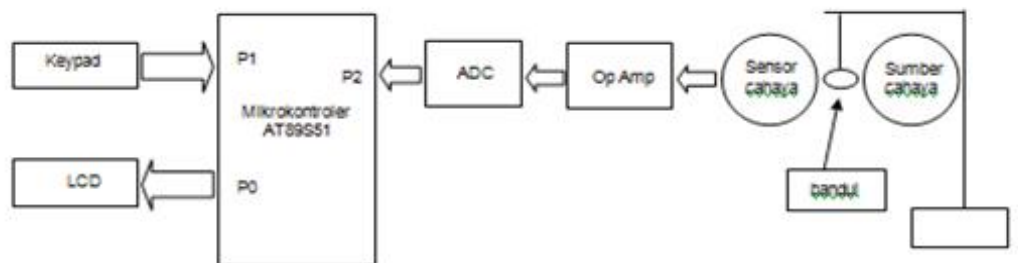

Gambar 3. Perancangan alat ayunan matematis secara digital

\section{Osilasi Cairan}

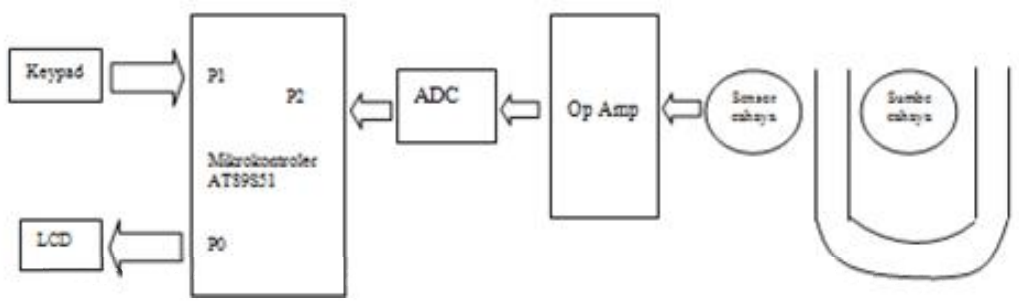

\section{Pembuatan Perangkat Lunak}

Software dari sistem ditulis menggunakan bahasa $\mathrm{C}$ dan compiler yang digunakan adalah CVAVR. Adapun flow chart nya adalah sebagai berikut :

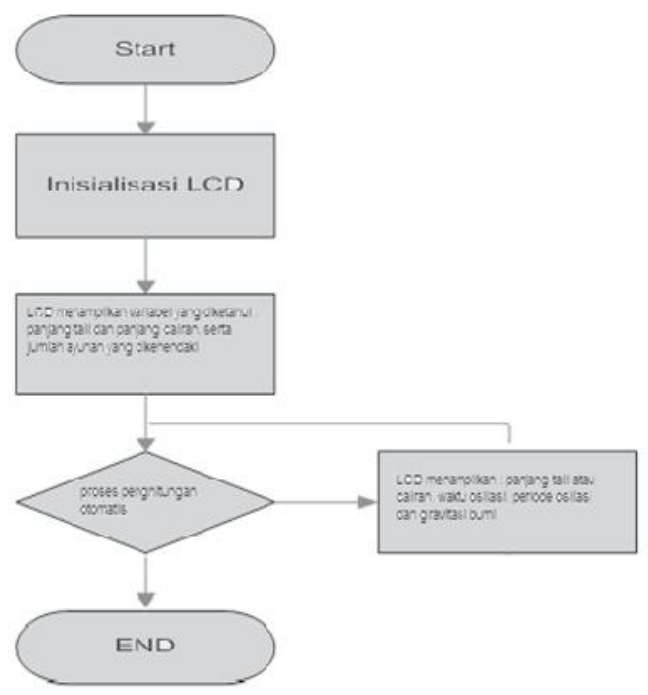

Gambar 5. Flow chart Diagram Sistem 
Pada flow chart diagram tersebut dapat dilihat pada saat pertama kali sistem dihidupkan, sistem melakukan inisialisasi pada LCD. Selanjutnya sistem menampilkan menu data yang dikehendaki dan menampilkannya pada LCD. Adapun menu yang akan ditampilkan adalah : 1 . data waktu (detik) 2 . data periode 3. data perhitungan mencari percepatan gravitasi. Setelah memilih menu yang dikehendaki, maka tombol start kita tekan, sehingga sistem akan mendeteksi berapa kali osilasi. Dengan algoritma pemrograman $\mathrm{C}$, maka hasil akan ditampilkan pada layar LCD.

\section{Cara Kerja Keseluruhan Alat}

Dengan memberikan algoritma program pada mikrokontroler untuk memerintahkan sistem digitalisasi alat laboratorium praktikum fisika guna menampilkan waktu $n$ osilasi pada praktikum ayunan matematis atau osilasi cairan kemudian menampilkan waktu $(t)$, periode $(\mathrm{T})$, dan nilai percepatan gravitasi bumi (g) pada layar LCD. Adapun metodenya adalah mensensor jumlah $\mathrm{n}$ osilasi dari ayunan matematis atau osilasi cairan kemudian keluaran dari sensor diproses pada mikrokontroler ATMega8535 dan hasilnya akan ditampilkan pada layar LCD.

\section{HASIL DAN ANALISA DATA}

Setelah semua rancangan digitalisasi alat praktikum osilasi cairan dan ayunan matematis)secara digital selesai dibuat, maka langkah selanjutnya adalah menguji alat yang dibuat sudah apakah siap digunakan dan sudah sesuai dengan yang diinginkan. 


\section{Hasil Alat Digitalisasi Osilasi Cairan}

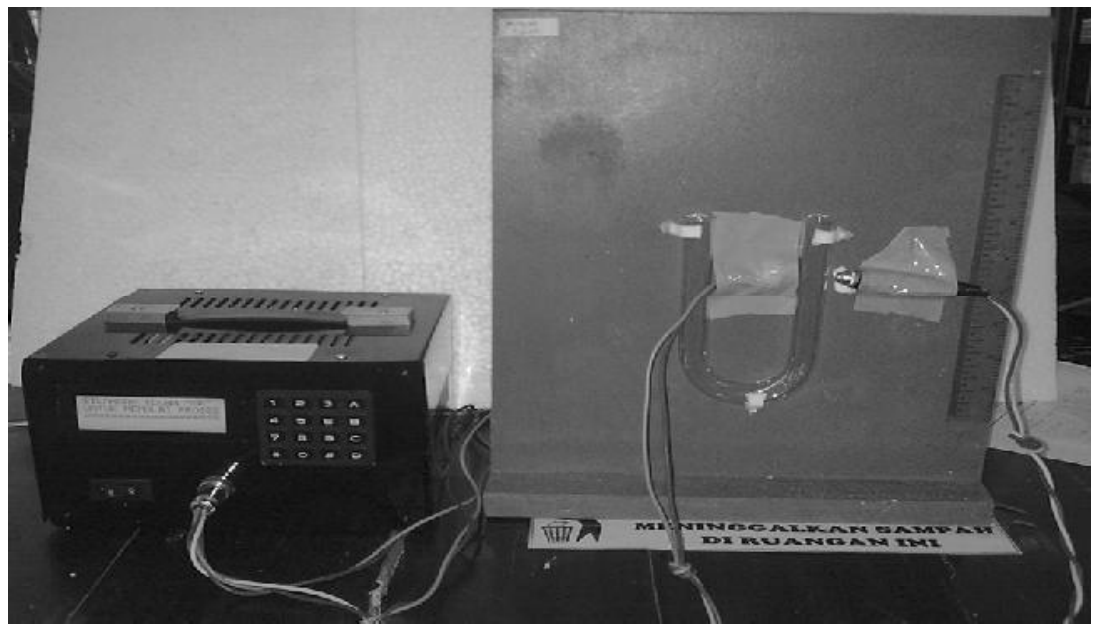

Gambar 6. Gambar keseluruhan alat praktikum osilasi cairan secara digital

\section{Hasil Pengujian}

Pengambilan data secara manual

\begin{tabular}{|c|c|c|c|c|c|c|}
\hline $\begin{array}{c}\text { panjang } \\
\text { tabung } \\
\text { luar } \\
\text { (meter) }\end{array}$ & $\begin{array}{l}\text { panjang } \\
\text { tabung } \\
\text { dalam } \\
\text { (meter) }\end{array}$ & $\begin{array}{c}\text { panjang } \\
\text { tabung } \\
\text { luar+dalam } \\
\text { (meter) }\end{array}$ & $\begin{array}{l}\text { banyak } \\
\text { ayunan }\end{array}$ & $\begin{array}{l}\text { waktu } \\
\text { (detik) }\end{array}$ & $\begin{array}{c}\text { periode } \\
\text { (detik) }\end{array}$ & $\begin{array}{c}\text { Gravi } \\
\text { tasi } \\
\left(\mathrm{m} / \mathrm{s}^{2}\right)\end{array}$ \\
\hline 12 & 8 & 0,10 & 3 & 2,0 & 0,67 & 9,48 \\
\hline
\end{tabular}

Data secara digital

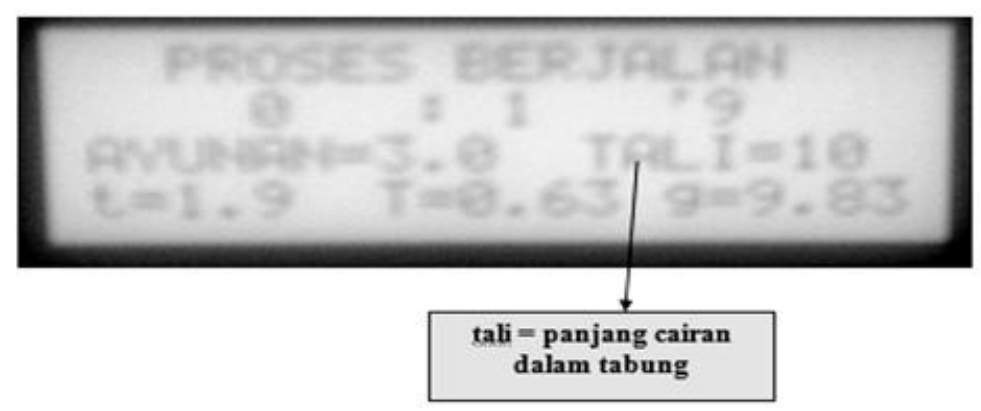


Hasil Alat Digitalisasi Ayunan Matematis

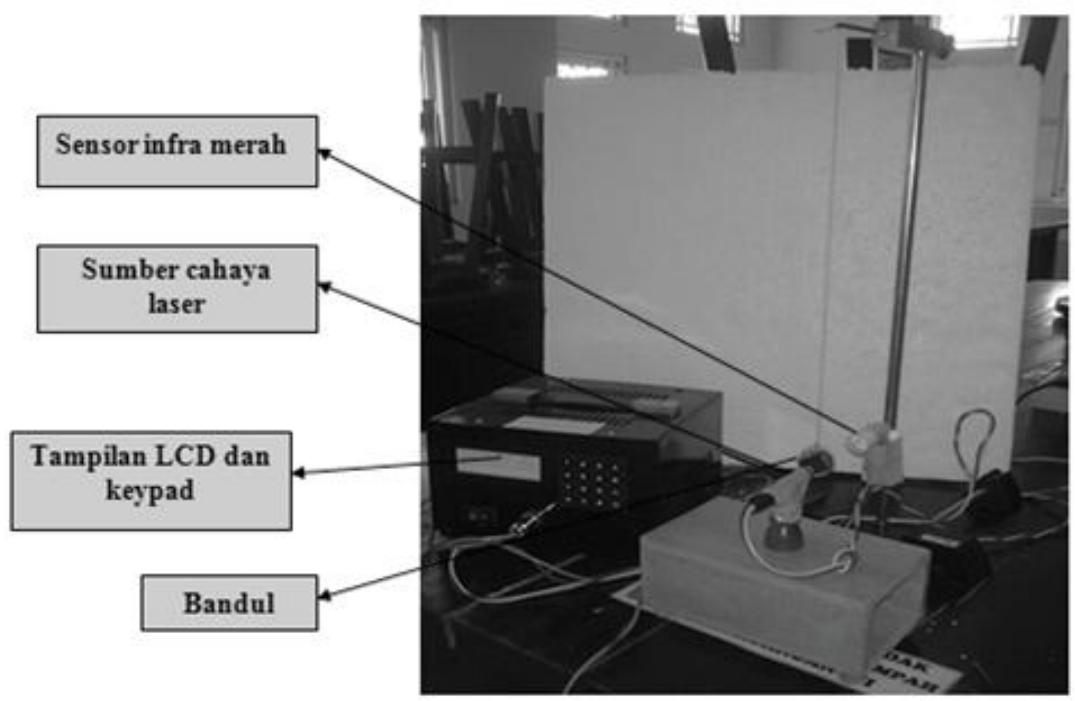

Gambar 7. Gambar keseluruhan alat praktikum ayunan matematis secara digital

\section{Hasil Pengujian}

\begin{tabular}{|c|c|c|c|c|}
\hline $\begin{array}{l}\text { Panjang tali } \\
\text { (meter) }\end{array}$ & $\begin{array}{l}\text { banyak } \\
\text { ayunan }\end{array}$ & $\begin{array}{l}\text { waktu } \\
\text { (detik) }\end{array}$ & $\begin{array}{c}\text { periode } \\
\text { (detik) }\end{array}$ & $\begin{array}{c}\text { Gravitasi } \\
\left(\mathrm{m} / \mathrm{s}^{2}\right)\end{array}$ \\
\hline 0,4 & $10 x$ & 12.5 & 1.25 & 10,09 \\
\hline
\end{tabular}

\section{Data secara digital}

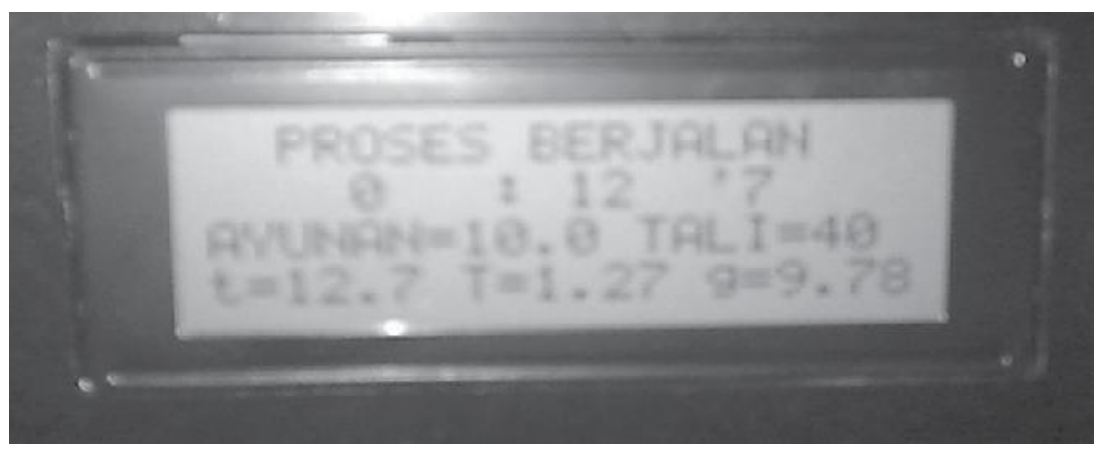




\section{Analisa Data}

Data pada percobaan osilasi cairan dan ayunan matematis dapat dibandingkan bahwa data yang didapat dari percobaan secara manual dan dengan alat praktikum secara digital terlihat bahwa data hasil percobaan osilasi cairan dengan menggunakan alat secara digital didapat nilai gravitasi bumi sebesar $9,83 \mathrm{~m} / \mathrm{s}^{2}$ dan untuk percobaan ayunan matematis didapat nilai gravitasi bumi sebesar $9,78 \mathrm{~m} / \mathrm{s}^{2}$, dari kedua percobaan tersebut didapat nilai gravitasi bumi mendekati nilai referensi yaitu 9,8 m/ $\mathrm{s}^{2}$. Sedangkan untuk percobaan secara manual diperoleh nilai gravitasi bumi untuk osilasi cairan sebesar $9,48 \mathrm{~m} / \mathrm{s}^{2}$ dan ayunan matematis sebesar 10,09 m/s $\mathrm{s}^{2}$ dari hasil yang diperoleh kedua percobaan secara manual tersebut didapat nilai yang masih jauh mendekati nilai referensi gravitasi bumi yaitu $9,8 \mathrm{~m} / \mathrm{s}^{2}$.

\section{KESIMPULAN}

Berdasarkan penelitian yang dilakukan dapat diambil beberapa kesimpulan, yaitu :

1. Pembuatan digitalisasi alat Laboratorium Fisika Fakultas Tarbiyah IAIN Walisongo (alat praktikum osilasi cairan dan ayunan matematis) sudah dapat berfungsi sesuai yang diinginkan.

2. Pada sistem ini didapatkan nilai percepatan gravitasi untuk osilasi cairan sebesar $9,83 \mathrm{~m} / \mathrm{s}^{2}$ dan untuk ayunan matematis sebesar $9,78 \mathrm{~m} / \mathrm{s}^{2}$ yang lebih mendekati nilai gravitasi refrensi yaitu $9,8 \mathrm{~m} / \mathrm{s}^{2}$ dibandingkan secara manual yaitu untuk osilasi cairan sebesar $9,48 \mathrm{~m} / \mathrm{s}^{2}$ dan ayunan matematis sebesar $10,09 \mathrm{~m} / \mathrm{s}^{2}$. 


\section{DAFTAR PUSTAKA}

Anonim. 2012. Keypad. http://delta-electronic.com/article/ wp-content/uploads/2008/09/an0060.pdf. diunduh tanggal 3 September 2012 pukul 20.30

Anonim. 2012. Laser. http://id.wikipedia.org/wiki/Laser. diunduh pada tanggal 21 September 2012 pukul 09.00

Anonim. 2012. LCD. http://www.delta-elektronik. com,DatasheetLCD. dinduh tanggal 3 September 2012 pukul 22.00

Halliday, R., 1996, Fisika Jilid 1, Erlangga, Jakarta.

Lingga. W. 2006. Mikrokontroler AVR Seri ATMega8535 Simulasi, Hardware, dan Aplikasi. Andi Offset. Yogyakarta

Link. Wolfgang. 1993. Pengukuran, Pengendalian dan Pengaturan dengan PC. PT Elexmedia Komputindo. Jakarta 